\title{
Teaching NeuroImages: A fuzzy determination of stroke onset
}

James E. Siegler, MD, Whitley W. Aamodt, MD, and Kelley A. Humbert, MD

Neurology ${ }^{\circledR}$ 2019;92:e2395-e2396. doi:10.1212/WNL.0000000000007511

\author{
Correspondence \\ Dr. Siegler \\ james.siegler@ \\ uphs.upenn.edu
}

Figure Selected head and neck imaging, including photograph
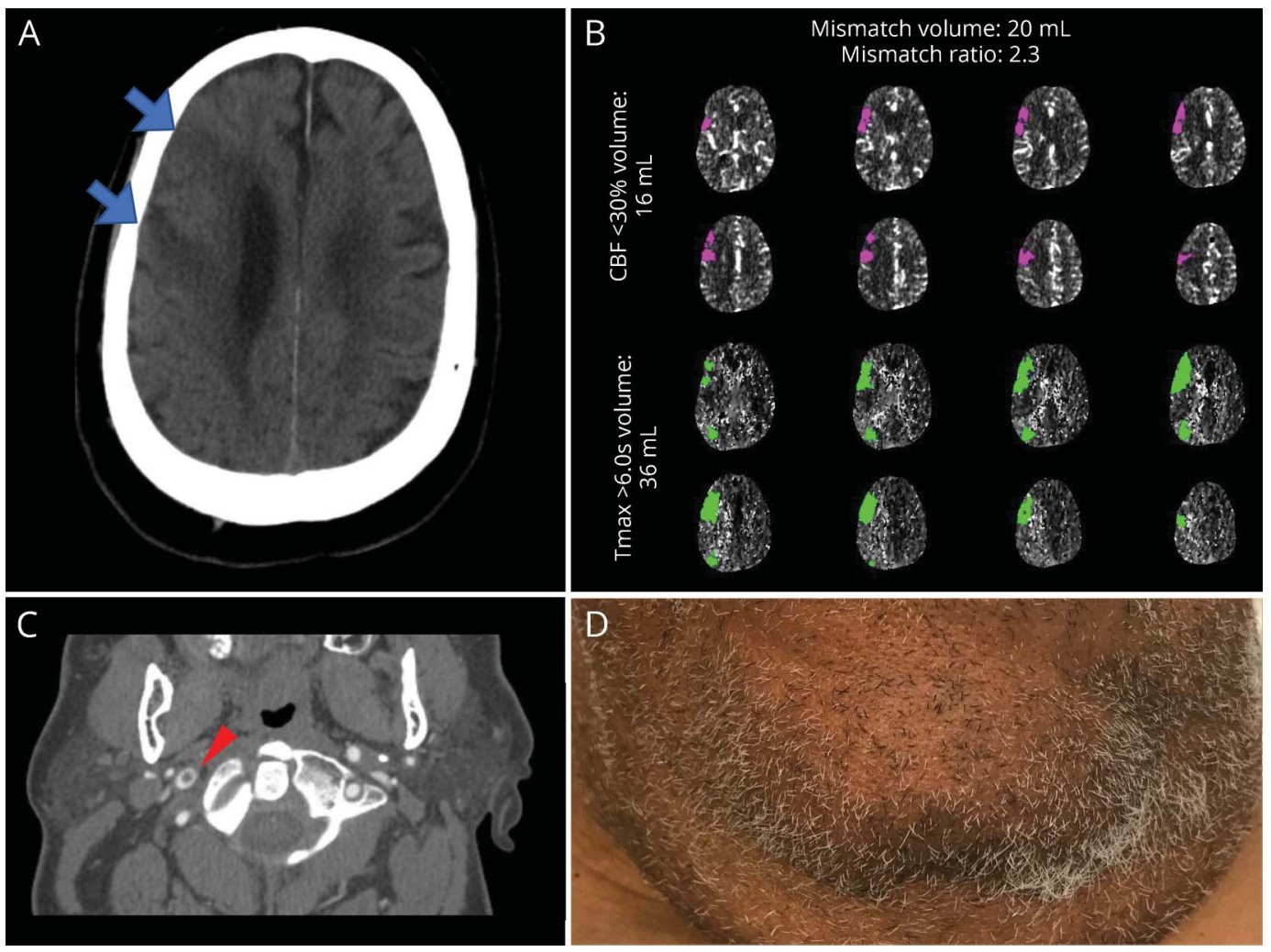

(A) Representative axial head CT with areas of hypoattenuation (blue arrows) concerning for subacute infarction. (B) CT perfusion pattern of ischemic core (regional cerebral blood flow [CBF] $<30 \%$ [pink]) and penumbra (Tmax $>6.0$ s [green]) volumes using RAPID (IschemaView, Redwood, CA), indicating a recent ischemic insult with potentially salvageable penumbra as calculated by the mismatch volume ( $20 \mathrm{~mL}$ tissue). (C) Non-occlusive thrombus (red arrowhead) without significant associated stenosis in the cervical right internal carotid artery. (D) In addition to the left lower facial weakness, the left side of the patient's face has lengthier facial hair compared to the right. This indicates he had shaved the right side more recently than the left.

A 73-year-old man with hypertension presented with left hemiparesis and left hemineglect of unclear duration. CT with angiography of the head and neck showed subacute infarcts of the right frontal lobe and a right internal carotid artery thrombus, with corresponding perfusion abnormalities that would have qualified him for thrombectomy (figure). ${ }^{1}$ On closer examination, his facial hair asymmetry suggested a matured hemineglect to his left face. Based on the unenhanced imaging findings and facial hair asymmetry, we estimated his stroke onset to be more than 24 hours prior to evaluation, thereby disqualifying him for thrombectomy.

\section{MORE ONLINE}

\section{$\rightarrow$ Teaching slides}

links.lww.com/WNL/ A885 
Although we are increasingly reliant upon perfusion imaging to inform treatment decision-making, the time of symptom onset remains critical. When symptom onset is unknown, subtle clues may be helpful.

\section{Author contributions}

J.E. Siegler: drafting/revising the manuscript, data acquisition, study concept or design, analysis or interpretation of data, accepts responsibility for conduct of research and final approval, contribution of vital reagents/tools/patients, acquisition of data, study supervision. W.W. Aamodt: drafting/ revising the manuscript, data acquisition, accepts responsibility for conduct of research and final approval. K.A. Humbert: data acquisition, analysis or interpretation of data, accepts responsibility for conduct of research and final approval.

\section{Study funding}

No targeted funding reported.

\section{Disclosure}

The authors report no disclosures relevant to the manuscript. Go to Neurology.org/N for full disclosures.

\section{Reference}

1. Powers WJ, Rabinstein AA, Ackerson T, et al; American Heart Association Stroke Council. 2018 Guidelines for the early management of patients with acute ischemic stroke: a guideline for healthcare professionals from the American Heart Association/ American Stroke Association. Stroke 2018;49:e46-e110. 


\title{
Neurology
}

\author{
Teaching NeuroImages: A fuzzy determination of stroke onset \\ James E. Siegler, Whitley W. Aamodt and Kelley A. Humbert \\ Neurology 2019;92;e2395-e2396 \\ DOI 10.1212/WNL.0000000000007511
}

This information is current as of May 13, 2019

\section{Updated Information \& Services}

References

Subspecialty Collections

Permissions \& Licensing

Reprints including high resolution figures, can be found at: http://n.neurology.org/content/92/20/e2395.full

This article cites 1 articles, 1 of which you can access for free at: http://n.neurology.org/content/92/20/e2395.full\#ref-list-1

This article, along with others on similar topics, appears in the following collection(s):

CT

http://n.neurology.org/cgi/collection/ct

Infarction

http://n.neurology.org/cgi/collection/infarction

Information about reproducing this article in parts (figures,tables) or in its entirety can be found online at:

http://www.neurology.org/about/about_the_journal\#permissions

Information about ordering reprints can be found online:

http://n.neurology.org/subscribers/advertise

Neurology ${ }^{\circledR}$ is the official journal of the American Academy of Neurology. Published continuously since 1951, it is now a weekly with 48 issues per year. Copyright (O 2019 American Academy of Neurology. All rights reserved. Print ISSN: 0028-3878. Online ISSN: 1526-632X.

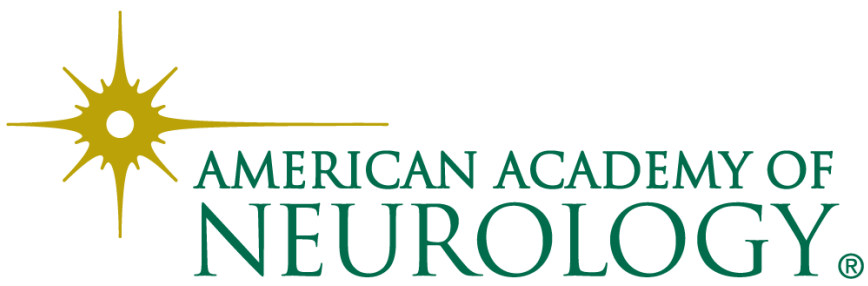

